\title{
Responses to supplementation by dairy cows given low pasture allowances in different seasons 1. Pasture intake and substitution
}

\author{
J. W. Penno ${ }^{1}$, K. A. Macdonald ${ }^{1}$, C. W. Holmes ${ }^{3}$, S. R. Davis ${ }^{2}$, G. F. Wilson ${ }^{3}$, I. M. Brookes ${ }^{3}$ and E. R. Thom ${ }^{1 \dagger}$ \\ ${ }^{1}$ Dexcel, Private Bag 3221, Hamilton, New Zealand \\ ${ }^{2}$ ViaLactia Biosciences (NZ Ltd), PO Box 109-185, Auckland, New Zealand \\ ${ }^{3}$ Massey University, Private Bag 11 222, Palmerston North, New Zealand \\ ${ }^{\dagger}$ Corresponding author. E-mail: errol.thom@dexcel.co.nz
}

\begin{abstract}
Two factorial experiments were designed to determine the effects of stage of lactation, and season of the year, on cow responses to supplementary feeding. These experiments were conducted over consecutive years with 128 high genetic merit multiparous Holstein-Friesian cows in early, mid and late lactation in spring, summer, autumn and winter. At each stage of lactation, and in each season of the year, cows were offered a restricted pasture allowance (25 to $35 \mathrm{~kg}$ dry matter (DM) per cow per day), either unsupplemented (control) or supplemented with $50 \mathrm{MJ}$ metabolizable energy (ME) per cow per day in experiment 1 and $80 \mathrm{MJ}$ ME per cow per day in experiment 2. Two different supplements were offered, namely, rolled maize grain (MG) and a mixture of foods (BR) formulated to nutritionally balance the diet. In experiment 2, a fourth treatment consisting solely of a generous pasture allowance (60 to $75 \mathrm{~kg} D \mathrm{DM}$ per cow per day, $A P)$ was introduced. Offering $M G$ and $B R$ increased DM intake (DMI). At the restricted pasture allowance, increasing total ME allowance (MEA) by offering supplementary foods increased ME intake (MEI) by 0.68 (s.e. 0.047) MJ per extra MJ ME offered. This highly significant $(\mathrm{P}<0.001)$ linear relationship was consistent across seasons, and did not diminish at higher MEA. In experiment 2, cows in early lactation had lower substitution rates than mid and late lactation cows irrespective of season. Substitution rate was higher when higher pasture allowance or quality of pasture on offer enabled the unsupplemented cows to achieve higher DMI from pasture than at other times of the year. These results suggest that one of the key factors determining the intake response to supplementary foods is pasture allowance. Within spring calving dairying systems, the largest increases in total DMI per $\mathrm{kg}$ of supplement offered is likely when offering supplements to early lactation cows grazing restricted allowances of high quality pasture.
\end{abstract}

Keywords: dairy cows, grazing, pasture intake, substitution, supplementary feeding.

\section{Introduction}

Grazed temperate pasture provides a low-cost source of nutrients for dairy production, but is characterized by seasonal variations in growth and nutrient composition, both of which can limit animal performance. When pasture is the main food source for spring calving herds, conservation of surplus pasture and strategic early drying-off are often used to align herd food requirements with pasture production (Macdonald and Penno, 1998). In addition, supplementary foods can be used to increase nutrient supply during periods of inadequate pasture growth (Clark, 1993), or to achieve levels of animal performance that are higher than those achievable from pasture alone. However, supplements are often more expensive than pasture and should only be used when the value of the extra milk produced exceeds the total cost of providing the food.

Previous research has shown that offering supplementary foods to grazing dairy cows reduces pasture intake (Leaver,
1985), and the extent to which the supplement increases total nutrient intake is the primary determinant of the animal response to supplements. Substitution of pasture by supplements increased as pasture allowance increased (Grainger and Mathews, 1989), and as level of supplementary feeding increased (Meijs and Hoekstra, 1984; Bines, 1985). The extent of substitution is a function of pasture and supplement availability, relative acceptability, and the capacity of the cow to consume nutrients to meet her requirements.

In seasonal pastoral dairying systems, the energy and nutrient requirements of the herd are closely related to stage of lactation (Auldist et al., 1998), and energy and nutrient supply are closely associated with season of the year (Holmes, 1987; Auldist et al., 1998). Edwards and Parker (1994) as well as Lean et al. (1996) have claimed that many published supplementary feeding studies underestimated potential responses to supplements, by failing to balance 
cow nutritional requirements with pasture nutrient supply. Thus, in the experiments discussed in this paper, pasture allowance was controlled to ensure that the supplements offered were consumed and as well one treatment was nutritionally balanced. This paper presents intake and substitution associated with supplementation throughout lactation while animal performance is reported separately (Penno et al., 2006).

\section{Material and methods}

\section{Animals and pastures}

Two experiments were conducted at the Dairying Research Corporation (now Dexcel), Hamilton, New Zealand $\left(37^{\circ}\right.$ $47^{\prime} \mathrm{S}, 175^{\circ} 19^{\prime} \mathrm{E} ; 40 \mathrm{~m}$ a.s.I.) between September 1996 and July 1998. Each experiment involved 128 high genetic merit multiparous Holstein-Friesian cows (bred for superior milk production under the New Zealand breeding index system). Cows were bred to calve in four calving date groups of 32 so that calving occurred at intervals of approximately three months, beginning on 12 July, 25 October, 20 January, or 15 April. Cows (no. $=2$ or less in each calving group) due to calve outside the eight week planned calving period were induced to calve (Chesterton and Marchant, 1985) within 6 weeks of the planned start of calving. The assessment of cow performance at threemonthly intervals ensured that in all seasons cows were either in early, mid or late lactation and some were not milking (Table 1).

Pastures were predominantly ryegrass (Lolium perenne L.) and white clover (Trifolium repens L.). Pasture was offered as a sole diet or with supplements during 35-day test periods. Between test periods, all cows grazed pasture and were offered pasture silage as required. At the end of the first lactation, six cows from each calving group were culled on the basis of reproductive failure, health, age and genetic merit, and were replaced with primiparous cows one month before the planned start of calving.

The pastures were on a Te Rapa peaty silt loam soil, a humic aquic haplorthod in soil taxonomy (Soil Survey Staff, 1990), or a humose groundwater-gley podzol in the New Zealand classification (Hewitt, 1998). Annually, 150, 50 , and $60 \mathrm{~kg} / \mathrm{ha}$ of $\mathrm{N}, \mathrm{P}$ and $\mathrm{K}$, respectively, were applied as fertilizer. Phosphate was applied in a single dressing in autumn and $\mathrm{K}$ fertilizer applied as a single application in spring. Nitrogenous fertiliser was applied after most grazings, except during periods of summer moisture deficit or following heavy winter rainfall.

\section{Experimental design}

Experiment 1 was conducted in a $3 \times 3 \times 4$ factorial design with three feeding treatments imposed on three groups of cows (no. $=8$ per group) in early, mid and late lactation, at four times of the year representing spring, summer, autumn and winter. The experiment consisted of four 35-day test periods, commencing 30 September 1996 (spring), 27 January 1997 (summer), 14 April 1997 (autumn) and 30 June 1997 (winter). Stage of lactation was defined as the average days in milk (at the start of each test period) over the four seasons and was 66, 157 and 251 for early, mid and late lactation cows, respectively.

Cows were offered a restricted pasture allowance of 25 to $35 \mathrm{~kg}$ DM per cow per day (measured to ground level) which was either unsupplemented (control), or supplemented with either rolled maize grain (MG) (50 MJ ME per cow per day) or as a mixture of supplementary foods and minerals formulated to balance the total diet (BR) (50 MJ ME per cow per day), including the grazed pasture (Table 2). Pasture allowance varied because pasture structure (ratio of green leaf to dead material) and dry-matter intake (DMI) of each control group (early, mid and late lactation) was restricted to 0.75 of the measured intake during the 7-day uniformity period that preceded each test period.

Before each 7-day uniformity period cows were grazed within their calving group and offered an allowance appropriate to their stage of lactation (Macdonald and Penno, 1998). At the start of the study, cows within each calving date group were blocked on age, genetic merit, milk yield, live weight and condition score, and randomly assigned to one of the three feeding treatments; milk production of cows in early, mid and late lactation averaged 18.8, 15.2 and $12.9 \mathrm{~kg}$ per cow per day, respectively, with corresponding live weights of 426,436 and $449 \mathrm{~kg}$ per cow. On completion of each test period, cows were re-allocated to a different feeding treatment group, so that individual cows were not on the same feeding treatment for two consecutive test periods.

During the 7-day uniformity period cows within each calving date group were grazed together and offered a generous pasture allowance of $60 \mathrm{~kg}$ DM per cow per day without supplements to enable covariate analysis. The uniformity period was followed by 14 days of adjustment to the feeding treatments with milk production and intake measurements made over the last 21 days of each test period. On completion of each test period, cows in early and mid lactation

Table 1 Stage of lactation (early, mid, late or not lactating (NL)) in relation to cow calving date group and season

\begin{tabular}{lccccccc}
\hline \hline Calving date & & & & & & & \\
Group & Spring & & Summer & & Autumn & & Winter \\
\hline July (Winter) & Early & $\longrightarrow$ & Mid & $\longrightarrow$ & Late & $\longrightarrow$ & NL \\
October (Spring) & Mid & $\longrightarrow$ & Late & $\longrightarrow$ & NL & $\longrightarrow$ & Early \\
January (Summer) & Late & $\longrightarrow$ & NL & $\longrightarrow$ & Early & $\longrightarrow$ & Mid \\
April (Autumn) & NL & $\longrightarrow$ & Early & $\longrightarrow$ & Mid & $\longrightarrow$ & Late \\
\hline \hline
\end{tabular}

$\mathrm{NL}=$ not lactating. 
Supplementation and pasture intake by dairy cows -1

were again grazed together by calving date group, and were offered a generous pasture allowance for 28 days so carryover effects could be measured. Cows in late lactation were dried off on completion of each 35-day test period and there were no carryover measurements.

Experiment 2 was conducted in a $4 \times 3 \times 4$ partially complete factorial design with four feeding treatments imposed on four groups of cows $($ no. $=8$ ) in early lactation (averaging 52 days in milk over the four seasons of the year) and three feeding treatments imposed on similar groups of cows in mid and late lactation (averaging 126 and 215 days in milk, respectively) at the start of each test period. The feeding treatments were applied in each of four seasons (spring, summer, autumn and winter).

Three of the feeding treatments in early lactation were based on a restricted pasture allowance of approximately 25 to $35 \mathrm{~kg}$ DM per cow per day (control) with the addition of no supplements, $80 \mathrm{MJ}$ ME per cow per day of rolled maize grain (MG), or $80 \mathrm{MJ}$ ME per cow per day as a mixture of supplementary foods and minerals formulated to balance the total diet (BR); the fourth treatment was a generous pasture allowance (AP) of (60 to $75 \mathrm{~kg}$ DM per cow per day). The AP treatment was added to ensure there was a treatment where cows were offered a generous allowance providing a measure of how severe the restricted level was in the other feeding treatments. Only the control, MG and BR feeding treatments were imposed on cows in mid and late lactation. The experiment was conducted in four 35-day periods commencing 1 September and 24 November 1997, and 23 March and 8 June 1998. Cows in early, mid and late lactation averaged $18.1,14.3$ and $12.0 \mathrm{~kg}$ per cow per day, respectively, at the start of the study, with comparable live weights of 436,429 and $443 \mathrm{~kg}$ per cow.

The experimental schedule and measurements were the same for both experiments.

\section{Supplementary foods}

The maize grain offered with treatments $M G$ and $B R$ had been processed through a single roller crusher so that each kernel was broken into three or four pieces. The Spartan computer program (Van de Haar et al., 1992) was used to formulate BR, taking into account the expected chemical composition of the pasture (Holmes et al., 1987) and the predicted pasture DMI from known relationships between pasture allowance and intake (Holmes, 1987). The BR included mineral, and occasionally protein and or energy supplements to meet cow nutrient requirements according to the Cornell Net Carbohydrate and Protein System (CNCPS; Fox et al., 1992) and the measured nutrient composition of foods and degradation rate parameters for pasture from the CNCPS Feeds Library. The formulation was adjusted using the Spartan computer program to provide sufficient nutrients for cows in early lactation to achieve milk yields proportionately 0.25 higher than those being achieved immediately before the experimental treatments started. Maximum supplementation was $4.9 \mathrm{~kg}$ DM per cow per day in experiment 1 and $6.9 \mathrm{~kg}$ DM per cow per day in experiment 2 (Table 2).

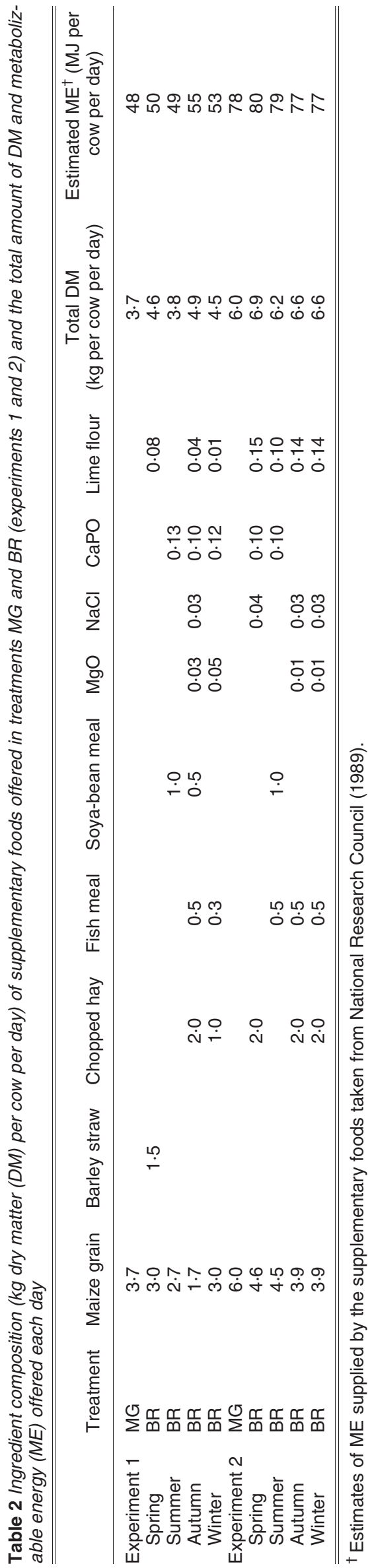


The CNCPS model predicted that ME intake (MEI) would be the first limiting factor for cows at all stages of lactation when offered a restricted pasture allowance. Overcoming this limitation by offering rolled maize grain to the MG group during experiments 1 and 2 increased ME supply (Table 2) but resulted in a metabolizable protein (MP) or specific amino acid supply, limiting milk yield. The model suggested that this inadequate protein supply resulted from a suboptimal rumen environment due to insufficient effective fibre (eNDF) in the rumen in spring, autumn and winter, and from a low crude protein $(\mathrm{CP})$ intake in summer.

In spring of experiment 1, supplementary eNDF was provided as barley straw to the BR treatment groups, but this did not mix satisfactorily with the other food ingredients and was replaced by chopped ryegrass hay in the winter and autumn test periods. The hay was also included in all but the summer test period of experiment 2 (Table 2).

Fish meal was included in the BR supplement to increase MP supply in the autumn and winter of experiment 1, and in summer, autumn and winter of experiment 2. Soya-bean meal provided rumen degradable protein in summer and autumn test periods of experiment 1 , and the summer of experiment 2. Macrominerals were included in the BR mixture to provide adequate $\mathrm{Mg}, \mathrm{Ca}, \mathrm{P}$ and $\mathrm{Na}$ (Table 2).

Supplementary foods were offered individually to cows in stalls immediately after the morning milking. Refusals were collected and weighed. During test periods, cows were offered a fresh allowance of pasture daily, immediately after the morning milking. Portable electric fences were used to contain each group on the area of pasture allocated for that day, such that each group was offered the same pasture allowance. The cows had continuous access to water in a portable trough.

\section{Experimental measurements}

Group pasture intake. Pre- and post-grazing pasture mass was estimated daily on each area by calibrated visual assessment (Thom et al., 1986). Once each week, the pasture mass of 12 quadrats (each $0.33 \mathrm{~m}^{2}$ ), representing the range of pre- and post-grazing pasture masses present on the experimental areas, were visually assessed, and the quadrats then cut to ground level with a portable shearing hand-piece. Harvested material was collected, washed to remove soil and faecal contamination, and was oven-dried for $48 \mathrm{~h}$ at $100^{\circ} \mathrm{C}$ before weighing. The weight of the dried material provided an estimate of the pasture mass above ground level. This was related to the visually assessed pasture mass by linear regression and the resultant equation used to correct the visual assessments made during that week. The group pasture DMI was calculated as the difference between the adjusted pre- and post-grazing pasture mass on the area grazed by each group.

Cow pasture intake. Individual cow DMI was estimated using an alkane faecal marker technique (Dove and Mayes, 1991). During experiment 1, all cows were dosed with gelatine capsules at $07: 30$ and 16:00 h on days 21 to 32 of each test period. Each capsule contained $350 \mathrm{mg}$ of synthetic $\mathrm{C}_{32}$ alkane in a cellulose carrier. During experiment 2, cows were dosed on day 21 with a Captec $^{\mathrm{TM}}$ (Captec NZ, Nufarm, Auckland, New Zealand) slow release alkane capsule with a known release rate of about $400 \mathrm{mg} \mathrm{C}_{32}$ per day. Faecal samples (approx. $200 \mathrm{~g}$ wet) were collected per rectum immediately before each morning and evening milking on days 26 to 32 of each test period. Each sample was dried in a ventilated oven at $60^{\circ} \mathrm{C}$ for $96 \mathrm{~h}$. Dried material was finely ground and sub-sampled to accumulate a composite sample for each cow.

Representative pasture samples were taken by hand clipping to grazing height (visually estimated) from days 26 to 32 of each test period, coinciding with collection of faecal material. Pasture samples were immediately frozen before being freeze-dried and finely ground for alkane analysis. Daily intakes of supplements were measured for each cow during the test period and alkane concentrations of both MG and the BR mixture were measured.

Faecal, pasture and supplement alkane concentrations were measured according to the procedures of Mayes et al. (1986) using gas chromatography. Pasture intakes of each cow were calculated using the equation of Dove and Mayes (1991).

Pasture chemical composition. Pasture samples were hand clipped daily to grazing height (visually estimated) from the areas to be grazed by each treatment group. Samples were bulked over each week of the test period, before a representative sub-sample was oven dried at $60^{\circ} \mathrm{C}$ for $48 \mathrm{~h}$, ground and analyzed by near infrared reflectance spectroscopy (Corson et al., 1999) for concentrations of CP, lipid, ash, acid-detergent fibre, neutral-detergent fibre, soluble carbohydrate, and organic matter digestibility from which ME was derived (Agricultural Research Council, 1980).

\section{Statistical analysis}

Experiments 1 and 2 were analysed separately. Residual maximum likelihood (REML) procedures of Genstat 5 Release 4.2b (Genstat Committee, 1997) were used for analysis of pasture, supplement and total DMI, using stage of lactation, season, food and their interactions as fixed effects. Days-in-milk, as a deviation from the stage of lactation group mean days-in-milk, was used as a covariate, and cow was specified as a random effect. Pasture, supplement and total DMl for each test period are the predicted means, adjusted for imbalance in covariates and the number of observations of measurements from days 29 to 35 of each test period in experiments 1 and 2. Predicted means are presented with the maximum standard error of the difference (s.e.d.) between comparable means.

MEI was calculated from the product of the estimated DMI and the estimated ME of the pasture fed. ME substitution rate was calculated as the mean pasture ME intake of the respective control group, minus the mean pasture $\mathrm{ME}$ intake of each treatment group receiving either MG or BR at 
Supplementation and pasture intake by dairy cows -1

the same stage of lactation and season, divided by the ME intake from the supplement. The linear model of Data Desk 6 (Velleman, 1997) was used sequentially to calculate expected mean ME substitution rate for stage of lactation, season, and food, separately for each experiment. The relationships between pasture DMI and the DM substitution rate was determined by plotting the pasture DMI of each control group against the substitution rate after feeding $M G$ and BR supplements (calculated as for ME substitution rate). Significance of slope differences was tested by firstly fitting a model with common slopes and different intercepts and secondly a model with different slopes and different intercepts and then use of an $\mathrm{F}$ test to compare the models. The respective regression equations were calculated using Data Desk 6 (Velleman, 1997). The dry matter substitution rates of treatment group means of both experiments were then adjusted using the pasture DMI of control groups as a covariate, and analysed using the linear model of Data Desk 6 (Velleman, 1997).

\section{Results}

Cows grazed predominantly high quality pastures during experiments 1 and 2 (Table 3 ). The chemical composition of the pasture appeared to vary little between spring, autumn and winter. However, summer pasture had a lower organic matter digestibility and concentration of crude protein and higher concentration of acid and neutral detergent fibre than pasture in other seasons of the year.

The pasture allowances during each test period are presented in Table 4. During both experiments all groups were offered a similar pasture allowance within a test period, and these were lowest in winter and highest in summer because of variations in pasture structure.

\section{Experiment 1: pasture and supplement DMI}

No stage of lactation by food or season by food interactions $(P>0.05)$ were detected for pasture DMl or total DMI in experiment 1 (Table 5), however, there was a significant season by food interaction for supplement intakes $(P<0.01)$. There were also significant season by stage of

Table 3 Chemical composition, organic matter digestibility and metabolizable energy of pasture offered during the test periods in experiments 1 and 2 (g/kg dry matter, unless otherwise stated $)^{\dagger}$

ME

CP Lipid Ash ADF NDF CHO OMD (MJ/kg DM)

\begin{tabular}{lllrlllll}
\hline Experiment 1 & & & & & & & & \\
$\quad$ Spring & 216 & 38 & 104 & 220 & 406 & 114 & 836 & $12 \cdot 5$ \\
$\quad$ Summer & 187 & 42 & 95 & 236 & 434 & 110 & 730 & $10 \cdot 9$ \\
$\quad$ Autumn & 251 & 46 & 105 & 188 & 375 & 129 & 850 & $12 \cdot 7$ \\
$\quad$ Winter & 259 & 42 & 106 & 169 & 335 & 168 & 850 & $12 \cdot 7$ \\
Experiment 2 & & & & & & & & \\
$\quad$ Spring & 253 & 46 & 111 & 208 & 386 & 119 & 848 & $12 \cdot 6$ \\
$\quad$ Summer & 171 & 38 & 101 & 246 & 449 & 125 & 793 & $11 \cdot 8$ \\
$\quad$ Autumn & 235 & 44 & 112 & 233 & 423 & 101 & 799 & $11 \cdot 9$ \\
Winter & 247 & 43 & 118 & 233 & 426 & 104 & 831 & $12 \cdot 4$ \\
\hline \hline
\end{tabular}

${ }^{\dagger}$ Abbreviations are: $\mathrm{CP}=$ crude protein; $\mathrm{ADF}=$ acid-detergent fibre; NDF = neutral-detergent fibre; $\mathrm{CHO}=$ carbohydrate; OMD = organic matter digestibility; $\mathrm{ME}=$ metabolizable energy.
Table 4 Daily pasture allowances (kg dry matter per cow) offered to each treatment group during each test period

\begin{tabular}{lllll}
\hline \hline & \multicolumn{3}{c}{ Stage of lactation } \\
\cline { 3 - 5 } & AP $^{\dagger}$ & Early & Mid & Late \\
\hline Experiment 1 & & & & \\
$\quad$ Spring & & 25 & 24 & 24 \\
Summer & & 36 & 37 & 37 \\
Autumn & & 31 & 31 & 30 \\
Winter & & 24 & 24 & 23 \\
Experiment 2 & & & & \\
$\quad$ Spring & 65 & 30 & 30 & 30 \\
Summer & 76 & 36 & 35 & 35 \\
Autumn & 76 & 32 & 32 & 32 \\
Winter & 62 & 25 & 24 & 24 \\
\hline \hline
\end{tabular}

${ }^{\dagger} \mathrm{AP}=$ generous pasture allowance, imposed on early lactation cows only.

lactation interactions for pasture and total DMI, but these are not presented, as they do not relate to feeding. Season by stage of lactation by food interactions were not detected.

Offering supplementary foods increased total DMI compared with cows offered the control diet at all stages of lactation and at all times of the year. Total DMI increased from an average of $10.2 \mathrm{~kg}$ DM per cow per day across all seasons in the control treatment to 13.2 and $13.5 \mathrm{~kg}$ DM per cow per day where MG or BR was offered, respectively.

The overall mean DMI of cows offered the control treatment (pasture only) was highest in autumn and lowest in summer and winter (Table 5). Offering supplements of MG and BR reduced $(P<0.01)$ overall mean pasture DMI from $10.2 \mathrm{~kg}$ DM per cow per day to 9.6 , and $9.1 \mathrm{~kg}$ DM per cow per day, respectively. In the summer and winter test periods there were no differences between the pasture DMI of cows offered the control and supplemented treatments. In spring, cows offered the BR consumed less pasture $(P<0.05)$ than the cows offered the control and MG diets, and in autumn cows offered both supplementary foods consumed less pasture $(P<0.05)$ than cows offered pasture only.

Offering the $M G$ and $B R$ treatments reduced pasture $D M I$ in mid lactation $(P<0.05)$ but had no effect on DMI in late lactation. In early lactation there was no difference $(P<0.05)$ between the pasture DMI of control and MG cows, however, the BR supplement did reduce pasture DMI $(P<0.05)$. Pasture DMI of cows offered the BR supplement was similar at all stages of lactation.

Experiment 2: pasture and supplement DMI

Interactions relating to feeding (season by food and stage of lactation by food) were all significant for pasture, supplement and total DMI (Table 6). Season by stage of lactation interactions were also detected for pasture and total DMI, but as for experiment 1 these are not presented. Season by stage of lactation by food interactions were generally not significant.

In all seasons, mid and late lactation cows offered BR and MG had a reduced pasture DM intake compared with those 
Penno, Macdonald, Holmes, Davis, Wilson, Brookes and Thom

Table 5 Average daily pasture allowance and daily intakes ( $\mathrm{kg}$ dry matter per cow) of cows during experiment 1, as measured during the final week of each test period

\begin{tabular}{|c|c|c|c|c|c|c|c|c|c|c|c|c|c|c|c|c|}
\hline \multirow[b]{3}{*}{ Food (F) } & \multirow{3}{*}{$\begin{array}{l}\text { Pasture } \\
\text { allowance }\end{array}$} & \multicolumn{9}{|c|}{ Stage (St) } & \multirow[b]{3}{*}{ s.e.d. ${ }^{\dagger}$} & \multirow{2}{*}{\multicolumn{5}{|c|}{ Significant effects }} \\
\hline & & \multicolumn{3}{|c|}{ Early } & \multicolumn{3}{|c|}{ Mid } & \multicolumn{3}{|c|}{ Late } & & & & & & \\
\hline & & Control & MG & BR & Control & MG & BR & Control & MG & BR & & Season (S) & \multirow[t]{2}{*}{ St } & $\mathrm{F}$ & $\mathrm{S} \times \mathrm{F}$ & St $\times F$ \\
\hline \multicolumn{16}{|l|}{ Spring } & \\
\hline Pasture & 24 & $11 \cdot 2$ & $12 \cdot 2$ & $9 \cdot 1$ & $10 \cdot 6$ & $9 \cdot 3$ & $8 \cdot 1$ & $9 \cdot 9$ & $9 \cdot 8$ & $8 \cdot 9$ & 0.92 & ** & $\star \star$ & ** & \multirow{3}{*}{$\star *$} & \\
\hline Supplement & & - & $3 \cdot 2$ & $4 \cdot 6$ & - & $3 \cdot 6$ & 4.5 & - & $3 \cdot 4$ & $4 \cdot 5$ & 0.11 & & & & & \\
\hline Total & & $11 \cdot 2$ & $15 \cdot 4$ & $13 \cdot 7$ & $10 \cdot 6$ & $12 \cdot 8$ & $12 \cdot 7$ & $9 \cdot 9$ & $13 \cdot 2$ & 13.5 & 0.95 & ** & $\star *$ & ** & & \\
\hline \multicolumn{17}{|l|}{ Summer } \\
\hline Pasture & \multirow[t]{3}{*}{37} & $9 \cdot 1$ & $9 \cdot 9$ & $8 \cdot 2$ & $12 \cdot 4$ & $10 \cdot 7$ & $11 \cdot 6$ & $10 \cdot 0$ & $9 \cdot 5$ & 9.8 & & & & & & \\
\hline Supplement & & - & 3.7 & $3 \cdot 8$ & - & $3 \cdot 7$ & $3 \cdot 8$ & - & $3 \cdot 7$ & $3 \cdot 8$ & & & & & & \\
\hline Total & & $9 \cdot 1$ & $13 \cdot 5$ & $12 \cdot 0$ & $12 \cdot 4$ & $14 \cdot 4$ & $15 \cdot 5$ & $10 \cdot 0$ & $13 \cdot 2$ & $13 \cdot 6$ & & & & & & \\
\hline \multicolumn{17}{|l|}{ Autumn } \\
\hline Pasture & \multirow[t]{3}{*}{31} & $12 \cdot 0$ & $10 \cdot 6$ & $9 \cdot 8$ & $12 \cdot 1$ & $10 \cdot 2$ & $10 \cdot 8$ & $10 \cdot 7$ & $10 \cdot 1$ & $9 \cdot 6$ & & & & & & \\
\hline Supplement & & - & $3 \cdot 7$ & 4.9 & - & $3 \cdot 7$ & 4.9 & - & $3 \cdot 7$ & 4.9 & & & & & & \\
\hline Total & & $12 \cdot 0$ & $14 \cdot 3$ & $14 \cdot 7$ & $12 \cdot 1$ & 13.9 & $15 \cdot 7$ & $10 \cdot 7$ & $13 \cdot 8$ & 14.5 & & & & & & \\
\hline Pasture & 24 & $9 \cdot 1$ & $7 \cdot 4$ & $8 \cdot 5$ & $8 \cdot 4$ & $8 \cdot 2$ & $7 \cdot 5$ & $7 \cdot 0$ & $7 \cdot 1$ & $7 \cdot 5$ & & & & & & \\
\hline Supplement & & - & 3.7 & 4.4 & - & $3 \cdot 7$ & $4 \cdot 3$ & - & $3 \cdot 6$ & $4 \cdot 3$ & & & & & & \\
\hline Total & & $9 \cdot 1$ & $11 \cdot 1$ & $12 \cdot 9$ & $8 \cdot 4$ & 11.9 & 11.8 & $7 \cdot 0$ & $10 \cdot 7$ & $11 \cdot 8$ & & & & & & \\
\hline
\end{tabular}

${ }^{\dagger}$ Maximum standard error of the difference for all paired comparison of interaction means. When significant treatment interactions are detected the significance levels for treatment main effects are omitted. MG = maize grain, BR = balanced ration.

offered the control treatment $(P<0.05)$. Late lactation cows in spring offered the BR treatment showed the largest reduction with pasture intake declining by $4.8 \mathrm{~kg}$ per cow per day. Offering BR and MG to early lactation cows had inconsistent effects on pasture DMI in spring and winter and no effects in summer and autumn. The pasture DMI of all cows offered the control treatment was higher in spring than in other seasons, except for early lactation cows in winter when intakes were similar. Early lactation cows offered the AP treatment also followed these seasonal trends, however, the pasture DMI of the cows offered this treatment in winter exceeded those offered the control treatment by $3.2 \mathrm{~kg}$ per cow per day.
Supplementation of cows with BR and MG usually increased total DMI, regardless of season and stage of lactation (Table 6). Exceptions occurred in summer when mid lactation cows showed a non-significant response ( $+2 \mathrm{~kg}$ per cow per day) to both BR and MG supplements, and when late lactation cows showed a non-significant response $(+1.5 \mathrm{~kg}$ per cow per day) to the BR supplement in spring. Intake responses to supplements were greatest for early lactation cows in summer and autumn, exceeding $6 \mathrm{~kg}$ per cow per day.

Within each season, MEI of each treatment group offered the restricted pasture allowance was directly related to the total ME allowance (MEA) from pasture plus supplement, and

Table 6 Average daily pasture allowance and daily intakes (kg dry matter per cow) of cows during experiment 2 as measured during the final week of each test period

\begin{tabular}{|c|c|c|c|c|c|c|c|c|c|c|c|c|c|c|}
\hline \multirow[b]{3}{*}{ Food $(F)$} & \multirow{3}{*}{$\begin{array}{l}\text { Pasture } \\
\text { allowance }\end{array}$} & \multicolumn{10}{|c|}{ Stage (St) } & \multirow[b]{3}{*}{ s.e.d. ${ }^{\dagger}$} & \multirow{2}{*}{\multicolumn{2}{|c|}{ Significant effects }} \\
\hline & & \multicolumn{4}{|c|}{ Early } & \multicolumn{3}{|c|}{ Mid } & \multicolumn{3}{|c|}{ Late } & & & \\
\hline & & Control & $\mathrm{AP}$ & MG & $\mathrm{BR}$ & Control & MG & $\mathrm{BR}$ & Control & $M G$ & $\mathrm{BR}$ & & Season $\times F$ & St $\times F$ \\
\hline \multicolumn{15}{|l|}{ Spring } \\
\hline Pasture & 30 & $12 \cdot 5$ & 14.3 & $13 \cdot 6$ & 10.5 & 14.5 & $12 \cdot 0$ & 11.9 & $16 \cdot 7$ & $14 \cdot 1$ & 11.9 & 1.07 & ** & ** \\
\hline Supplement & & - & - & 4.6 & $6 \cdot 2$ & - & $5 \cdot 7$ & 5.5 & - & 5.5 & $6 \cdot 3$ & 0.23 & ** & * \\
\hline Total & & 12.5 & $14 \cdot 3$ & $18 \cdot 2$ & $16 \cdot 7$ & 14.5 & $17 \cdot 7$ & $17 \cdot 4$ & $16 \cdot 7$ & $19 \cdot 6$ & $18 \cdot 2$ & $1 \cdot 10$ & ** & * \\
\hline \multicolumn{15}{|l|}{ Summer } \\
\hline Pasture & 35 & $8 \cdot 6$ & 8.8 & $8 \cdot 8$ & $8 \cdot 8$ & $12 \cdot 2$ & $8 \cdot 2$ & 8.2 & $11 \cdot 2$ & 9.9 & 8.0 & & & \\
\hline Supplement & & - & - & $6 \cdot 0$ & $6 \cdot 1$ & - & $5 \cdot 8$ & $5 \cdot 8$ & - & $5 \cdot 8$ & $6 \cdot 2$ & & & \\
\hline Total & & $8 \cdot 6$ & 8.8 & 14.8 & 14.9 & $12 \cdot 2$ & $14 \cdot 0$ & 14.0 & 11.2 & $15 \cdot 7$ & $14 \cdot 2$ & & & \\
\hline \multicolumn{15}{|l|}{ Autumn } \\
\hline Pasture & 32 & $10 \cdot 3$ & $10 \cdot 7$ & $10 \cdot 3$ & 8.8 & $9 \cdot 8$ & 7.3 & $8 \cdot 7$ & $9 \cdot 1$ & 7.5 & $8 \cdot 1$ & & & \\
\hline Supplement & & - & - & $6 \cdot 0$ & $6 \cdot 6$ & - & 6.0 & $6 \cdot 6$ & - & $5 \cdot 9$ & 6.5 & & & \\
\hline Total & & $10 \cdot 3$ & $10 \cdot 7$ & $16 \cdot 3$ & $15 \cdot 4$ & $9 \cdot 8$ & $13 \cdot 3$ & $15 \cdot 3$ & $9 \cdot 1$ & 13.4 & $14 \cdot 6$ & & & \\
\hline \multicolumn{15}{|l|}{ Winter } \\
\hline Pasture & 24 & $11 \cdot 2$ & 14.4 & 8.3 & 9.3 & $12 \cdot 3$ & 9.9 & $8 \cdot 6$ & $12 \cdot 1$ & $10 \cdot 0$ & 8.9 & & & \\
\hline Supplement & & - & - & $5 \cdot 8$ & $6 \cdot 3$ & - & $5 \cdot 8$ & 6.5 & - & 6.0 & $6 \cdot 3$ & & & \\
\hline Total & & $11 \cdot 2$ & 14.4 & $14 \cdot 1$ & $15 \cdot 6$ & $12 \cdot 3$ & $15 \cdot 7$ & $15 \cdot 1$ & $12 \cdot 1$ & $16 \cdot 0$ & $15 \cdot 2$ & & & \\
\hline
\end{tabular}

${ }^{\dagger}$ Maximum standard error of the difference for all paired comparisons of interaction means. As significant treatment interactions were detected main effects are not presented. $A P=$ generous pasture allowance, $M G=$ maize grain, $B R=$ balanced ration . 


\section{Supplementation and pasture intake by dairy cows -1}

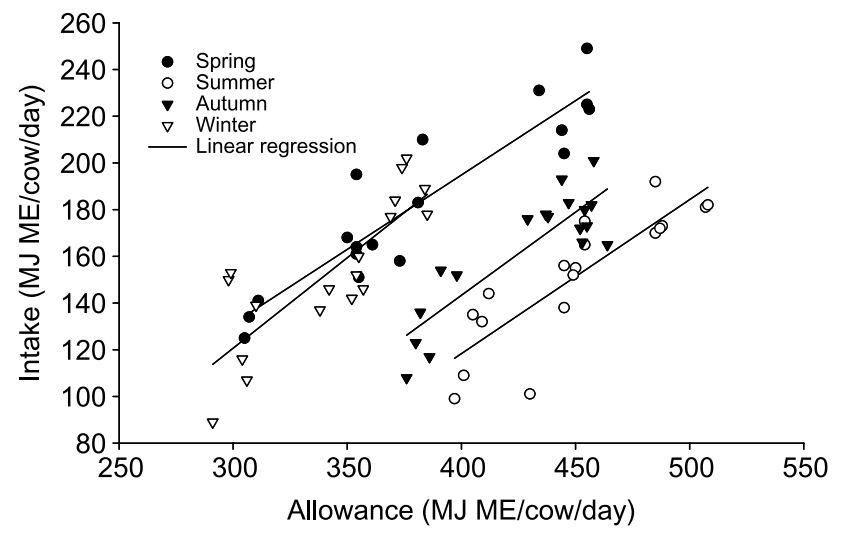

Figure 1 Relationships between the metabolizable energy allowance (MEA) from pasture plus supplement offered to each treatment group grazing a restricted pasture allowance and the metabolizable energy intake (MEI) of that group.

there was no significant difference between the slopes of the regression lines for each season (Figure 1). Seasonal regression equations were: spring $\mathrm{MEI}=-60.0+0.64$ (MEA) $\quad\left(R^{2}=0.85\right) ; \quad$ summer $\quad \mathrm{MEI}=-145.5+0.66$ (MEA) $\left(R^{2}=0.74\right)$; autumn $\mathrm{MEI}=-141.5+0.71$ (MEA) $\left(R^{2}=0.75\right) ; \quad$ winter $\quad \mathrm{MEI}=-111.7+0.77 \quad$ (MEA) $\left(R^{2}=0.67\right)$. Since slopes of these equations were not significantly different $(P=0.76)$ a model assuming common slopes for the seasons showed that increasing MEA by offering supplementary foods increased MEI by 0.68 (s.e. 0.047 ) MJ eaten per MJ ME offered. Over all seasons these relationships suggest an increase of $1.0 \mathrm{MJ}$ in MEA was associated with a 0.68 increase in $\mathrm{MEI}$, irrespective of whether the ME was derived from pasture or supplement. While season had little effect on the rate of increase in MEI resulting from additional food being offered, a constant MEA

Table 7 Average substitution rates (kg pasture dry matter (DM) per kg supplement DM) with maize grain (MG) and balanced ration $(B R)$ treatments offered at different stages of lactation and seasons in both experiments

\begin{tabular}{|c|c|c|}
\hline & \multicolumn{2}{|c|}{ Experiment } \\
\hline & 1 & 2 \\
\hline \multicolumn{3}{|c|}{ Stage of lactation } \\
\hline Early & 0.20 & 0.13 \\
\hline Mid & 0.33 & 0.49 \\
\hline Late & 0.09 & 0.41 \\
\hline s.e.d. & $0 \cdot 108$ & 0.098 \\
\hline Significance $^{\dagger}$ & & $\star *$ \\
\hline \multicolumn{3}{|l|}{ Season } \\
\hline Spring & 0.22 & 0.37 \\
\hline Summer & 0.15 & 0.34 \\
\hline Autumn & 0.33 & 0.21 \\
\hline Winter & 0.12 & 0.45 \\
\hline s.e.d. & 0.124 & 0.113 \\
\hline Significance $^{\dagger}$ & & \\
\hline \multicolumn{3}{|l|}{ Supplement } \\
\hline MG & 0.17 & 0.29 \\
\hline BR & 0.24 & 0.39 \\
\hline $\begin{array}{l}\text { s.e.d. } \\
\text { Significance }\end{array}$ & 0.080 & 0.080 \\
\hline
\end{tabular}

resulted in greater $\mathrm{MEI}$ in spring and winter than in summer and autumn (Figure 1).

No interactions were detected between stage of lactation and food, season and food, or stage of lactation and season for pasture DM substitution rate in either experiment (Table 7). Stage of lactation had no effect on substitution rate in experiment 1, however, in experiment 2 the substitution rate of early lactation cows was lower than those of cows in mid and late lactation $(P<0.01)$.

Substitution rate (DM substitution rate) increased as the pasture DMl of the respective control group increased according to the relationship:

$$
\begin{aligned}
\text { substitution rate }= & -0.495( \pm 0.163) \\
& +0.314( \pm 0.065) \text { PDMI }
\end{aligned}
$$

where PDMI is the pasture DMI of the respective control group per $100 \mathrm{~kg}$ of live weight. Individual relationships were derived for each season, stage of lactation and type of supplement (Table 8). No interactions were detected between experiments or supplement ME intake and the relationship between substitution rate and PDMI

\section{Discussion}

These experiments showed a strong relationship between pasture DMI and the substitution of pasture for supplements, for rotationally grazed New Zealand pastures. Some differences in this relationship were between the stage of lactation, season and form of supplement offered.

The total food intake of cows in these experiments was highly responsive to supplementary feeding at all stages of lactation, and at all times of the year. Stage of lactation had little effect on pasture DMl although DMI was expected to increase after calving. It is generally accepted that when access to food is unrestricted, the nutritional requirements for lactation results in DMI increasing rapidly after calving to a peak 8 to 16 weeks post partum, before steadily declining for the remainder of lactation (Bauman and Currie, 1980). This did not occur possibly because of the restricted pasture allowance used in these experiments.

Within each season, an increase of $1.0 \mathrm{MJ}$ ME in MEA resulted in a linear increase in $\mathrm{MEI}$ of $0.68 \mathrm{MJ}$. Large increases in food intake have been reported previously from similar studies. Stockdale and Trigg (1985) reported linear increases in DMI resulting from offering increasing amounts of supplement to cows grazing pasture allowances of 15 and $26 \mathrm{~kg}$ DM per cow per day, from which increases in $\mathrm{MEI}$ of 0.87 and 0.76 additional MJ ME per extra MJ ME offered as concentrates were achieved because pasture allowances were lower than in the current experiments. A lower value $(0.48)$ can be calculated from the results reported by Robaina et al. (1998). These responses are much larger than those of 0.2 to 0.3 increase in MJ ME intake as pasture per additional 1.0 MJ ME offered as calculated from data of Holmes (1987), Wales et al. (1998 and 1999), for similar cows offered pasture only across a range of pasture allowances. 
Penno, Macdonald, Holmes, Davis, Wilson, Brookes and Thom

Table 8 The relationship between the unsupplemented pasture dry matter intake per $100 \mathrm{~kg}$ live weight (PDMI) and substitution rate, and the average substitution rate (SR) adjusted for PDMI of groups in early, mid and late lactation in both experiments

\begin{tabular}{|c|c|c|c|c|c|}
\hline & Regression equation & Mean SR ${ }^{\dagger}$ & $R^{2}$ & Residual s.d. & Significance \\
\hline \multicolumn{6}{|c|}{ Stage of lactation } \\
\hline Early & $-0.359( \pm 0.426)+0.217( \pm 0.173) \mathrm{PDMI}$ & $0 \cdot 17$ & $0 \cdot 10$ & 0.27 & \\
\hline Mid & $-0.211( \pm 0.299)+0.238( \pm 0.114)$ PDMI & 0.35 & 0.24 & 0.17 & * \\
\hline Late & $-0.564( \pm 0.139)+0.349( \pm 0.058)$ PDMI & 0.29 & 0.72 & 0.13 & 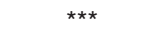 \\
\hline \multicolumn{6}{|c|}{ - } \\
\hline Spring & $-0.751( \pm 0.604)+0.368( \pm 0.210)$ PDMI & 0.14 & 0.24 & 0.29 & \\
\hline Summer & $-1.344( \pm 0.440)+0.722( \pm 0.198)$ PDMI & 0.34 & 0.57 & 0.20 & ** \\
\hline Autumn & $-0.334( \pm 0.262)+0.256( \pm 0.108)$ PDMI & 0.29 & 0.36 & 0.12 & * \\
\hline Winter & $-0.644( \pm 0.175)+0.394( \pm 0.073)$ PDMI & 0.32 & 0.75 & $0 \cdot 12$ & ** \\
\hline \multicolumn{6}{|c|}{ 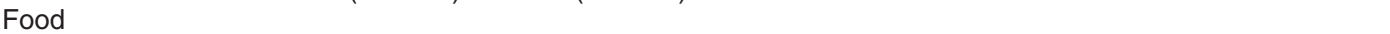 } \\
\hline MG & $-0.368( \pm 0.281)+0.244( \pm 0.113)$ PDMI & 0.23 & 0.18 & 0.25 & * \\
\hline BR & $-0.622( \pm 0.153)+0.384( \pm 0.061)$ PDMI & 0.32 & 0.64 & 0.14 & ** \\
\hline
\end{tabular}

${ }^{\dagger}$ Adjusted to a common PDMI of $2.5 \mathrm{~kg}$ DM per $100 \mathrm{~kg}$ live weight.

The substitution of pasture by supplements was higher during test periods when the allowance and quality of pasture on offer enabled cows to attain higher DMI from pasture alone. These findings are similar to Grainger and Mathews (1989) who reviewed supplementary feeding studies and suggested that the factor with greatest influence on substitution rate was the unsupplemented pasture intake, and that substitution rate could be predicted using the equation:

$$
\text { substitution rate }=-0.455 \times 0.315 \mathrm{PDMI}
$$

where PDMI is the unsupplemented pasture DMI per $100 \mathrm{~kg}$ live weight. Based on the average pasture DMI of cows in the control treatment of $2.5 \mathrm{~kg}$ per $100 \mathrm{~kg}$ live weight, the equation of Grainger and Mathews (1989) predicted a substitution rate of 0.32 compared with the average actual substitution rate of $0 \cdot 28$.

Several researchers have demonstrated increases in substitution rate as pasture allowance or the amount of supplementary food offered is increased (Meijs and Hoekstra, 1984; Stakelum, 1986a, b and c; Grainger and Mathews, 1989; Stockdale, 1996; Robaina et al., 1998; Wales et al., 1999). Increasing substitution rate at higher food allowances reflects the curvilinear relationship that exists between pasture allowance and intake and that also probably exists between MEA and MEI for any food at high allowances. This curvilinear relationship is also demonstrated by the increase in substitution rate associated with increases in PDMI.

Offering supplements resulted in lower substitution rate by early lactation cows than by mid and late lactation cows in experiment 2. Further, after substitution rate was adjusted for PDMI and the two experiments were analysed together, substitution rate was smaller in early lactation than in mid and late lactation. Cows with higher milk yield, and therefore larger metabolic demand, generally consume a higher proportion of the food on offer than lower producing cows (McGilloway and Mayne, 1996).

Although there was no direct relationship between season of the year and substitution rate, lower substitution rates were associated with periods of lower PDMI. Further, when substitution rate was adjusted for the higher pasture DMI of the control groups, the substitution rate was smaller in spring than during other times of the year, because of higher pasture DMl achieved by the control cows in spring.

The regression equations comparing PDMI and substitution rate suggest that in summer, substitution rate increased at a faster rate with increasing PDMI than at other times of the year, although there was no difference between the average substitution rate observed in summer, autumn or winter. In the summer test periods of both experiments, the early lactation cows offered the control treatment did not substitute much pasture for supplement, while for the same period in experiment 2, substitution was less for the mid and late lactation cows than for the early lactation cows offered the control treatment. At the same time, the offering of both supplements to mid and late lactation cows resulted in a greater substitution rate than was measured with the early lactation cows. A possible explanation for these results is that the cows had more difficulty ingesting nutrients from summer pasture than from pasture at other times of the year (Stockdale, 1985). This is predominantly because in the summer/ autumn there is an increase in the concentration of dead material and most of this is located at the base of the pasture (Holmes, 1987). Thus even though cows may graze to the same height the actual DM residual is higher in summer/ autumn. In Ireland it is recommended that the post-grazing residual pasture height should be no lower than $4 \mathrm{~cm}$ (Maher et al., 2003). In New Zealand, however, residuals of 1600 , 1750,2550 and $2450 \mathrm{~kg}$ DM per ha for winter, spring, summer and autumn, respectively, could represent a pasture height less than the $4 \mathrm{~cm}$ threshold. Substitution of pasture was also greatest when very early lactation cows continuously grazing on the least accessible pasture $(4 \mathrm{~cm}$ grazing height $v .8 \mathrm{~cm}$ ) were offered concentrates (Rook et al., 1994), despite having a low total intake. In contrast, Stockdale (1996) and Wales et al. (1999) reported that substitution rates of mid or late lactation dairy cows are increased as pasture mass increased at a constant pasture allowance. The latter workers clearly demonstrated increasing pasture substitution rate as both the allowance and mass of low quality irrigated summer pasture increased.

In both experiments, cows offered the BR supplement ate less pasture, and had higher substitution rates than cows offered the MG supplement, with the effect being greatest in 
spring. The main difference in composition between the two supplements during the spring test periods was the large amounts of low quality forage that were included in the BR to provide eNDF. The differences in pasture DMI between the $M G$ and BR groups in the spring test periods was 1.7 and $1.8 \mathrm{~kg}$ per cow per day in experiments 1 and 2, respectively, which are similar to the amounts of forage included in BR ( 1.5 and $2.0 \mathrm{~kg} \mathrm{DM}$ per cow per day, respectively). It is possible that some of the difference is due to experimental error caused by the refusals in the spring test periods that contained a disproportionately large amount of barley straw in experiment 1 , and chopped hay in experiment 2 . These foods provided a high proportion of the alkane in the BR supplement and, therefore, the pasture DMI of the BR groups may have been underestimated by the alkane technique. However, if all the alkane provided by the straw and hay was excluded from the DMI calculations, pasture DMI would have increased by only 0.5 and $0.3 \mathrm{~kg}$ DM per cow per day, respectively. This would have reduced the substitution rate from 0.47 to 0.38 , compared with only 0.13 from the MG in spring.

The BR treatments were designed to improve the nutritional characteristics of the whole diet and to optimise rumen digestion. Some authors have suggested that fibre based concentrates resulted in lower substitution rates than cereal grain supplements (Kellaway and Porta, 1993). However, other evidence suggests that the differences in substitution rate between concentrates based on starch or fibre are proportional to the ME concentration of the supplement (Meijs, 1986; Fisher at al., 1996). Alternatively, if the BR treatment did succeed in improving rumen efficiency, the whole diet may have yielded more ME and digestible nutrients than did the diet of cows offered the MG treatment. Thus, the energy and nutrient demand of cows offered the BR treatment may have been better satisfied at lower pasture DMI.

\section{Conclusions}

The data clearly demonstrate that the magnitude of the DM deficit has a larger effect on the DMI response of cows to supplements than either stage of lactation or season. If pasture availability, or the physical or chemical characteristics of the pasture on offer, limit the food intake of the grazing cow relative to her food requirements, total food intake is likely to be highly responsive to additional supplementary food inputs, giving rise to a low substitution rate.

\section{Acknowledgements}

The authors wish to thank the staff of the Dairying Research Corporation (now Dexcel) No. 3 Dairy, in particular the farm manager Brian Walsh. Thanks are also extended to Dr Harold Henderson (AgResearch) and Rhonda Hooper for assistance with the statistical analysis.

\section{References}

Agricultural Research Council. 1980. The nutrient requirements of ruminant livestock. CAB International, Farnham Royal, Slough.

Auldist, M. J., Walsh, B. J. and Thomson, N. A. 1998. Seasonal and lactational influences on bovine milk composition in New Zealand. Journal of Dairy Research 65: 401-411.
Bauman, D. E. and Currie, W. B. 1980. Partitioning of nutrients during pregnancy and lactation. A review of mechanisms involving homeostasis and homeorhesis. Journal of Dairy Science 63: 1514-1529.

Bines, J. A. 1985. Feeding systems and food intake by housed dairy cows. Proceedings of the Nutrition Society 44: 355-362.

Chesterton, R. N. and Marchant, R. M. 1985. Early induction of dairy cows. Proceedings of the second seminar of the Dairy Cattle Veterinarians' Society of the New Zealand Veterinary Association, vol. 2, p. 52

Clark, D. 1993. Silage for milk production. Proceedings of Ruakura dairy farmers' conference, vol. 45, pp. 41-46.

Corson, D. C., Waghorn, G. C., Ulyatt, M. J. and Lee, J. 1999. NIRS: forage analysis and livestock feeding. Proceedings of the New Zealand Grassland Association 61: 127-132.

Dove, H. and Mayes, R. W. 1991. The use of plant wax alkanes as marker substances in studies of the nutrition of herbivores: a review. Australian Journal of Agricultural Research 42: 913-952.

Edwards, N. J. and Parker, W. J. 1994. Increasing per cow milk solids production in a pasture-based dairy system by manipulating the diet: a review. Proceedings of the New Zealand Society of Animal Production 54: 267-273.

Fisher, G. E. J., Dowdeswell, A. M. and Perrott, G. 1996. The effects of sward characteristics and supplement type on the herbage intake and milk production of summer calving cows. Grass and Forage Science 51: 121-130.

Fox, D. G., Sniffen, C. J., O'Connor, J. D., Russell, B. J. and Van Soest, P. J. 1992. A net carbohydrate and protein system for evaluating cattle diets. Journal of Animal Science 70: 3578-3596.

Genstat Committee. 1997. Genstat for Windows command language manual, third edition, release $4 \cdot 2 b$. Rothamstead Experimental Station, Harpenden.

Grainger, C. and Mathews, G. L. 1989. Positive relationship between substitution rate and pasture allowance for cows receiving concentrates. Australian Journal of Experimental Agriculture 29: 355-360.

Hewitt, A. E. 1998. New Zealand soil classification. Landcare Research Science Series 1, second edition. Manaaki Whenua Press, Lincoln.

Holmes, C. W. 1987. Pastures for dairy cows. In Livestock feeding on pasture (ed. A. M. Nicol), New Zealand Society of Animal Production occasional publication no. 10, pp. 133-143.

Holmes, C. W., Wilson, G. F., MacKenzie, D. D. S., Flux, D. S., Brookes, I. M. and Davey, A. W. F. 1987. Milk production from pasture. Butterworths, Wellington.

Kellaway, R. C. and Porta, S. 1993. Factors affecting the response to supplementation. In Feeding concentrates: supplements for dairy cows (ed. R. Hopkins), pp. 117-147. Agmedia, Melbourne.

Lean, I. J., Parker, W. J. and Kellaway, R. C. 1996. Improving the efficiency of pasture-based dairying. Proceedings of the New Zealand Society of Animal Production 56: 270-275.

Leaver, J. D. 1985. Milk production from grazed temperate grassland. Journal of Dairy Science 52: 313-344.

Macdonald, K. A. and Penno, J. W. 1998. Management decision rules to optimise production on dairy farms. Proceedings of the New Zealand Society of Animal Production 58: 132-135.

McGilloway, D. A. and Mayne, C. S. 1996. The importance of grass availability for the high genetic merit dairy cow. In Recent advances in animal nutrition (ed. P. C. Garnsworthy, J. Wiseman and W. Haresign), pp. 135-169. Nottingham University Press, Nottingham.

Maher, J., Stakelum, G. and Rath, M. 2003. Effect of daily herbage allowance on the performance of spring-calving dairy cows. Irish Journal of Agricultural and Food Research 42: 229-241.

Mayes, R. W., Lamb, C. S. and Colgrove, P. M. 1986. The use of dose and herbage alkanes as markers for the determination of herbage intake. Journal of Agricultural Science, Cambridge 107: 161-170. 


\section{Penno, Macdonald, Holmes, Davis, Wilson, Brookes and Thom}

Meijs, J. A. C. 1986. Concentrate supplementation of grazing dairy cows. 2. Effect of concentrate composition on herbage intake and milk production. Grass and Forage Science 41: 229-235.

Meijs, J. A. C. and Hoekstra, J. A. 1984. Concentrate supplementation of grazing dairy cows. I. Effect of concentrate intake and herbage allowance on herbage intake. Grass and Forage Science 39: 59-66.

Penno, J. W., Macdonald, K. A., Holmes, C. W., Davis, S. R., Wilson, G. F., Brookes, I. M. and Thom, E. R. 2006. Responses to supplementation by dairy cows given low pasture allowances in different seasons. 2. Milk production. Animal Science 82: 671-681.

Robaina, A. C., Grainger, C., Moate, P., Taylor, J. and Stewart, J. 1998. Responses to grain feeding by grazing dairy cows. Australian Journal of Experimental Agriculture 38: 541-549.

Rook, A. J., Huckle, C. A. and Wilkins, R. J. 1994. The effects of sward height and concentrate supplementation on the performance of spring calving dairy cows grazing perennial ryegrass-white clover swards. Animal Production 58: 167-172.

Soil Survey Staff. 1990. Keys to soil taxonomy. Soil Management Support Services technical monograph no. 19, fourth edition. Virginia Polytechnic and State University, Blacksburg, VA.

Stakelum, G. 1986a. Herbage intake of grazing dairy cows. 1 Effect of autumn supplementation with concentrates and herbage allowance on herbage intake. Irish Journal of Agricultural Research 25: 31-40.

Stakelum, G. 1986b. Herbage intake of grazing dairy cows. 2. Effect of herbage allowance, herbage mass and concentrate feeding on the intake of cows grazing primary spring grass. Irish Journal of Agricultural Research 25: 41-51.

Stakelum, G. 1986c. Herbage intake of grazing dairy cows. 3. Effect of herbage mass, herbage allowance and concentrate feeding on the herbage intake of dairy cows grazing on midsummer pasture. Irish Journal of Agricultural Research 25: 179-189.
Stockdale, C. R. 1985. Influence of some sward characteristics on the consumption of irrigated pastured grazed by lactating dairy cows. Grass and Forage Science 40: 927-940.

Stockdale, C. R. 1996. Substitution and production responses when lactating dairy cows graze a white clover pasture supplemented with maize silage. Australian Journal of Experimental Agriculture 36: 771-776.

Stockdale, C. R. and Trigg, T. E. 1985. Effect of pasture allowance and level of concentrate feeding on the productivity of dairy cows in late lactation. Australian Journal of Experimental Agriculture 25: 739-744.

Thom, E. R., Sheath, G. W., Bryant, A. M. and Cox, N. R. 1986. Renovation of pastures containing paspalum 1. Persistence of overdrilled ryegrass and prairie grass and effect on seasonal pasture production. New Zealand Journal of Agricultural Research 29: 575-585.

Van de Haar, M., Bucholtz, H., Beverly, R., Emery, R., Allen, M., Sniffen, C. and Black, R. 1992. User's manual for Spartan dairy ration evaluator/balancer, version 2. Michigan State University Cooperative Extension Service, East Lansing.

Velleman, P. F. 1997. Data desk, statistics guide, version 6. Data Description, Ithaca, New York.

Wales, W. J., Doyle, P. T. and Dellow, D. W. 1998. Dry matter intake and nutrient selection by lactating dairy cows grazing irrigated pastures at different pasture allowances in summer and autumn. Australian Journal of Experimental Agriculture 38: 451-460.

Wales, W. J., Doyle, P. T., Stockdale, C. R. and Dellow, D. W. 1999. Effects of herbage mass, allowance, and level of supplement on nutrient intake and milk production of dairy cows in spring and summer. Australian Journal of Experimental Agriculture 39: 119-130.

(Received 18 October 2005-Accepted 17 May 2006) 
Responses to supplementation by dairy cows given low pasture allowances in different seasons 1. Pasture intake and substitution

Penno, J. W.

2006

http://hdl.handle.net/10179/9676

22/04/2023 - Downloaded from MASSEY RESEARCH ONLINE 